\title{
Detection of SHV Gene from Extended-Spectrum Beta-Lactamases (ESBLs) Producing Isolates in a Tertiary Care Hospital
}

\author{
Mili Rani Saha ${ }^{1}$, Sanya Tahmina Jhora ${ }^{2}$, Tarek Mahbub Khan³ ${ }^{3}$ Shikha Paul ${ }^{2}$, Durdana Chowdhury² \\ ${ }^{1}$ Department of Microbiology, BIRDEM, Dhaka. ${ }^{2}$ Department of Microbiology, Sir Salimullah Medical College, Mitford, Dhaka. \\ ${ }^{3}$ Department of Microbiology (MD-UKM)Allianze University College of Medical science;Penang, Malayasia
}

\begin{abstract}
Most ESBL Extended-Spectrum beta-lactamases (ESBLs) producing isolates carry TEM and SHV type betalactamases. Among these two types beta-lactamases SHV type was reported nosocomial infection outbreak in many countries in the world. The goal of this study was to see the rate of ESBLs production and also to detect SHV gene in those isolates recovered from a tertiary care hospital. A total of 354 samples were collected from Sir Salimullah Medical College and Mitford Hospital and from Burn Unit of Dhaka Medical College Hospital from January 2011 to December 2011. To detect ESBLs, Gram-negative organisms were subjected to Double Disc Synergy Test and SHV gene was detected from those ESBLs producing microorganisms by PCR. In this study, out of 354 different clinical samples 186 (89\%) were Gram-negative organisms. Among of these Gramnegative organisms 77 (41.40\%) were ESBL producing isolates detected by Double Disc Synergy Test. Out of these 77 isolates, 8 isolates (10.38\%) carried bla SHV gene. Among those ESBL producing 26.26\% Klebsiella spp. (4 out of 15 isolates) had SHV gene. Our findings showed that the majority of the ESBLs positive clinical isolates were Klebsiella spp. and high frequency of $\mathrm{SHV}$ genes were found in Klebsiella spp.
\end{abstract}

Keywords: Extended spectrum Beta-lactamase (ESBL), Double Disc Synergy Test, Polymerase chain reaction.

\section{Introduction:}

Extended-spectrum beta-lactamases (ESBLs) are the rapidly evolving group of beta-lactamase enzymes produced by the Gram negative bacteria, which have the ability to hydrolyse all cephalosporins and aztreonam but are inhibited by clavulanic acid $^{1}$. Incidence of ESBL producing strains are steadily increasing over the past years resulting in limitation of therapeutic options ${ }^{2}$. Early detection of multi resistant bacteria is important in defining therapies and for the isolation of patients, which is necessary to prevent the spread of these pathogens and also to prevent hospital-acquired (nosocomial) infections and outbreaks in the community ${ }^{3,4}$. Most ESBLs found in Esch. coli and Klebsiella pneumoniae carry the TEM and SHV type of $\beta$-lactamases ${ }^{5}$. These enzymes are generally located on large, transferable plasmids responsible for dissemination ${ }^{6}$. Since 1984, multi resistant

\section{Correspondence:}

Dr. Mili Rani Saha

Senior Research Officer

Department of Microbiology

BIRDEM Hospital, Dhaka
Klebsiella pneumoniae has been increasingly recognized as a cause of nosocomial infections ${ }^{7}$.

The SENTRY Antimicrobial Surveillance Program showed that ESBLs producing $K$. pneumoniae isolates were more prevalent in Latin America (45.5\%), followed by the Western Pacific region (24.6\%), Europe (22.6\%), the United States (7.6\%) and Canada (4.9\%). In Asia the prevalence of ESBLproducing $K$. pneumoniae and E. coli vary from $5 \%$ in Japan to $20-50 \%$ in other countries. In Europe, the prevalence of these organisms varies from country to country $3 \%$ in Sweden to $34 \%$ in Portugal) $)^{8,9,10}$. The colonization rate for Klebsiella pneumoniae is low in healthy individuals in the general population. But it is increased in hospitalized patients especially with long care facilities, health care manipulations eg. use of catheters ${ }^{11}$. The SHV-1 B-lactamase is most commonly found in Klebsiella spp. ESBLs in this family have amino acid changes most commonly at position 238 or 238 and 240. They are the predominant ESBL type in Europe, United States and are found world wide ${ }^{12}$. Among the SHVtype of B-lactamases, SHV-5 is found to be responsible for outbreaks of nosocomial infection in several countries ${ }^{13}$. 
SHV-5 is transferred from Klebsiella pneumoniae to Escherichia coli as well as to other members of Enterobacteriaceae family and poses a serious problem in the control of antibiotic resistance ${ }^{14}$. Klebsiella pneumoniae is an opportunistic pathogen that causes a significant proportion of community and hospital acquired infections including urinary tract, pneumonia, septicemia and soft tissue infections ${ }^{15}$. The prevalence of chromosomally encoded SHV ß-lactamase was reported worldwide during 2000 and 2001 ${ }^{16,17}$. SHV-type ESBLs currently predominate in surveys of resistant clinical isolates in Europe and America ${ }^{18}$.

Though presence of ESBLs have been reported from Bangladesh there is paucity of data regarding their molecular types. So the main aims of this study were to assess rate of ESBL producing isolates amongst the patients admitted in a tertiary care hospital in Bangladesh, alongside occurrence of SHV gene in those ESBL producing isolates by polymerase chain reaction.

\section{Materials and Methods}

This Cross sectional study was carried out in the department of Microbiology, Sir Salimullah Medical College, Dhaka for a period of one year from January 2011 to December 2011. A total 354 samples were collected from in patient and out patient departments of Sir Salimullah Medical College \& Mitford Hospital and Burn Unit, Dhaka Medical College Hospital. Hence, 3 categories of patients were included in this study, clinically diagnosed UTI patients, infected burn patients, patients with infected wound (surgical wound). All ESBL producing isolates detected by Double Disc Synergy Test. Klebsiella pneumoniae ATCC 700603 and Escherichia coli ATCC 25922 were used as positive and negative control respectively for ESBLs detection ${ }^{19}$.

\section{Culture}

Organisms (urine samples, surgical wound swab, burn wound swab, pus) were isolated by inoculating onto Blood agar and MacConkey's agar media and were identified by standard biochemical tests ${ }^{20}$.

\section{Double Disc Synergy Test}

Isolated Gram-negative bacteria were subjected to DDST. ESBLs production was considered positive when the inhibition zone around the test antibiotic disc was increased towards the augmentin disc $(20 \mu \mathrm{g}$ amoxicillin $+10 \mu \mathrm{g}$ clavulanic acid) which was placed in the centre of the plate and $20 \mathrm{~mm}$ apart from other discs ${ }^{21}$.

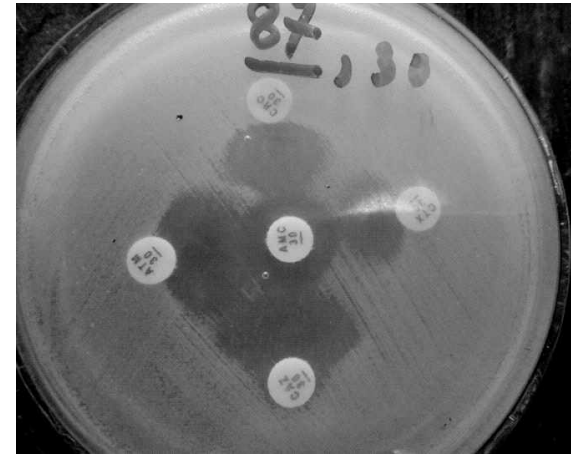

Figure-I: Positive ESBL isolate detected by DDST.

\section{Identification of SHV gene among the ESBL producing isolates by PCR:}

Broth culture: Stored organisms were subculture into Mueller-Hinton agar media from Nutrient agar slant. Bacterial colonies (5 colonies) were taken from MuellerHinton media using wire loop and inoculated into test tube containing Tryptic soy broth $(3 \mathrm{ml})$. Test tube was incubated at $37^{\circ} \mathrm{C}$ for 24 hours and was centrifuged at $4000 \mathrm{rpm}$ for 10 minutes. Supernatant was removed and the pellets were then transferred into an eppendorf tube for DNA extraction ${ }^{22}$.

\section{DNA extraction:}

A standard protocol was used for extraction of DNA. For the rapid lysis procedure, pellets were mixed with $300 \mu 1$ of distilled water. Bacterial suspension was heated at $95^{\circ} \mathrm{C}$ for 10 minutes and then quickly placed on ice. This suspension was then micro centrifuged at $14000 \mathrm{rpm}$ for 10 minutes. Supernatant was used as DNA extract. The supernatant was then taken in another eppendorf tube and stored at $-20^{\circ} \mathrm{c}$. The extracted DNA was used for amplification of DNA by PCR as template DNA.

PCR Primers:

Table I: Characteristics of the PCR primers of SHV gene ${ }^{19}$ :

\begin{tabular}{llcc}
\hline Primers & $\begin{array}{l}\text { Sequence } \\
\mathbf{5}^{\prime}-\mathbf{3}^{\prime}\end{array}$ & $\begin{array}{c}\text { Primer Size } \\
(\mathbf{b p})\end{array}$ & $\begin{array}{c}\text { Size of the PCR } \\
\text { products in bp }\end{array}$ \\
\hline SHV-F & GGG TTA TTC TTA TTT GTC GC & 20 & 30 \\
SHV-R & TTA GCG TTG CCA GTG CTC & 18 & \\
\hline
\end{tabular}

SHV-F $=$ Sulfhydril variable Forward

SHV-R $=$ Sulfhydril variable Reverse

\section{Steps involved in PCR protocol ${ }^{19}$}

The reaction was performed in a thermocycler using the following steps :

1. Initial denaturation of template DNA: Initial denaturation at $94^{\circ} \mathrm{C}$ for 5 minutes. 
2. Final denaturation of template DNA : 35 cycles at $94^{\circ} \mathrm{C}$ for 1 minute.

3. Annealing of primer : $52^{\circ} \mathrm{C}$ for $1 \mathrm{~min}$.

4. Extension of primer : $72^{\circ} \mathrm{C}$ for $1 \mathrm{~min}$.

5. A final extension for 10 minutes at $72^{\circ} \mathrm{C}$ was done to complete the synthesis of all amplicon.

The whole process of amplification took about 2.5 hours to complete PCR reaction.

\section{Detection and visualization of PCR products:}

The amplified PCR products were detected by $0.8 \%$ agarose (Invitrogen) gel electrophoresis, and then staining was done with ethidium bromide. The electrophoretic band was visualized in a gel documentation system by using UV transilluminator.

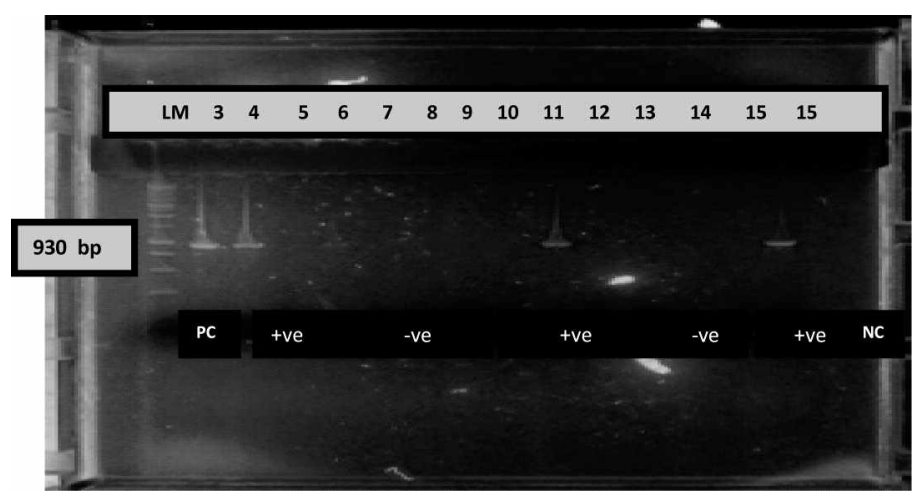

Figure (II): Agarose Gel showing fragment of bla SHV at $930 \mathrm{bp}$.

$\mathrm{PC}=$ Positive control

$\mathrm{NC}=$ Negative control

$\mathrm{LM}=$ Ladder

Lane 2 Ladder

Lane 3 Positive control (Klebsiella pneumoniae ATCC 700603)

Lane 4, 10, 14 are positive samples

Lane 15 Negative control (Escherichia coli ATCC 25922)

\section{Results}

Table-II shows rate of isolates of Gram-negative bacteria among total number of isolates from SSMC \& MH and DMCH. Among 354 samples 209 isolates were detected. Out of them 186 isolates (89\%) of Gram-negative bacteria had been identified from both hospitals.

Table-III shows among 186 isolates 77(41.40\%) isolates were phenotypically confirmed by DDST. Among them highest percentage of ESBL producing isolates were found in Klebsiella spp. Out of 20 Klebsiella spp. 15(75\%) isolates were phenotypically confirmed as ESBLs followed by Proteus spp. (45.45\%), Esch. coli (41.66\%) and Pseudomonas spp. (21.21\%).
Table-IV denotes presence of SHV gene among phenotypically confirmed ESBL producing isolates. Among 77 phenotypically confirmed ESBL producing isolates SHV genes were detected in only 8 isolates. Out of 50 ESBL producing Esch. coli, 4 isolates were (8\%) carrying SHV gene and among 15 ESBL producing Klebsiella spp., 4 isolates $(26.67 \%)$ were having SHV gene. No isolates of Proteus spp. and Pseudomonas spp. carried SHV gene.

Table II: Rate of isolates of Gram-negative bacteria among total number of isolates from SSMC \& MH and DMCH

\begin{tabular}{lccc}
\hline Name of hospitals & $\begin{array}{c}\text { Total No. of } \\
\text { tested samples }\end{array}$ & $\begin{array}{c}\text { Total No. of } \\
\text { isolates }\end{array}$ & $\begin{array}{c}\text { Number of Gram- } \\
\text { negative bacteria }\end{array}$ \\
\hline SSMC \& MH & 300 & $157(52.33)$ & $138(87.90)$ \\
DMCH & 54 & $52(96.30)$ & $48(92.31)$ \\
Grand Total & 354 & $209(59.04)$ & $186(89)$ \\
\hline
\end{tabular}

Note: Figures in parentheses represent percentage.

Table III: Distribution of ESBL producers detected by DDST among all Gram-negative organisms

\begin{tabular}{cc}
\hline Name of isolates & DDST positive \\
\hline Esch. coli $(\mathrm{n}=120)$ & $50(41.67)$ \\
Pseudomonas spp. $(\mathrm{n}=33)$ & $7(21.21)$ \\
Klebsiella spp. $(\mathrm{n}=20)$ & $15(75)$ \\
Proteus spp. $(\mathrm{n}=11)$ & $5(45.45)$ \\
Acinetobacter spp. $(\mathrm{n}=2)$ & $0(0)$ \\
\hline Total $(\mathbf{n}=\mathbf{1 8 6})$ & $\mathbf{7 7 ( 4 1 . 4 0 )}$
\end{tabular}

Note: Figures in parentheses represent percentage.

Table IV: Presence of SHV gene among phenotypically confirmed ESBL producing isolates

\begin{tabular}{lccc}
\hline Name of isolates & $\begin{array}{c}\text { Double Disc } \\
\text { Synergy Test } \\
\text { positive }\end{array}$ & \multicolumn{2}{c}{ SHV gene } \\
\hline & & Present & Absent \\
\hline Esch. coli & 50 & $4(8)$ & $46(92)$ \\
Klebsiella spp. & 15 & $4(26.67)$ & $11(73.33)$ \\
Proteus spp. & 5 & $0(0)$ & $5(100)$ \\
Pseudomonas spp. & 7 & $0(0)$ & $7(100)$ \\
\hline Total & $\mathbf{7 7}$ & $\mathbf{8 ( 1 0 . 3 9 )}$ & $\mathbf{6 9 ( 8 9 . 6 1 )}$ \\
\hline
\end{tabular}

Note: Figures in parentheses represent percentage.

\section{Discussion:}

Infectious diseases and their treatment are important problems in mankind's life and daily increase in bacterial resistance has raised patients expenses in recent years. ESBL production rate by Enterobacteriaceae has increased noticeably in two recent decades. Most of the hospitalized patients have immune deficiency and underlying disease and $K$. pneumoniae as an opportunistic pathogen is one of the 
most important causes of nosocomial infections especially in surgical wards and intensive care units ${ }^{23}$. There are different reports from all over the world in the case of prevalence of ESBLs bacteria. In the present study, out of 354 different samples 209 (59.04\%) organisms were isolated. Among them 186 (89\%) were Gram-negative organisms (Table-II). Among the 186 Gram-negative bacteria, phenotypically confirmed ESBLs were 77 (41.40\%) (Table-III). Majority of ESBL producers were observed among Klebsiella spp. (75\%) followed by Proteus spp. (45.45\%), Esch. coli (41.67\%), and Pseudomonas spp. (21.21\%). It is important to note that the percentage of ESBL producers has increased in this hospital from $25.23 \%$ to $41.40 \%$ over the last 4 years possibly due to indiscriminate and inappropriate use of $3 \mathrm{rd}$ generation of cephalosporin ${ }^{24,25}$. The prevalence of ESBLs has been reported to be $20 \%$ in some studies in southern east of Asia, in some regions it has been more than $60 \%{ }^{26}$. A study in the year 2004 has shown the prevalence of ESBLs in Europe to be $18.4 \%$ which is $40 \%$ in Netherland and 3\% in Sweden ${ }^{27}$. In the present study, ESBL producing Klebsiella spp. was more. The reason of this might be collection of samples from hospitalized patients and post-operative patients. Overcrowding, under stuffing or nursing workload might be the reasons for higher yielding of ESBL producing Klebsiella spp. in hospital environment. In this study phenotypically confirmed 77 ESBL producing isolates by DDST were also subjected to Polymerase chain reaction to see the presence of SHV gene. Among $77 \mathrm{ESBL}$ producing isolates 8 isolates $(10.38 \%)$ carried bla SHV gene (Table-IV). Among 50 isolates of Esch. coli, 4 isolates (8\%) carried SHV gene and out of 15 isolates of Klebsiella spp., 4 isolates (26.26\%) had SHV gene. SHV gene was not identified among Proteus spp. and Pseudomonas spp. (Table-IV). In a study at Indian hospital found SHV gene in $8.4 \%$ Klebsiella spp $^{28}$. In contrast to the findings of that the percentage of SHV gene carrying ESBL isolates was more in the present study. In another study reported that $20.3 \%$ isolates of Klebsiella spp. were containing SHV genes ${ }^{23}$. A study revealed that $50 \%$ of Klebsiella spp. had SHV-123. Now a days SHV-1 has been the most prevalent gene in most of the regions ${ }^{29}$.

To conclude, phenotypic methods are only screening methods for detection of ESBLs in a routine laboratory but genotypic methods help us to confirm the genes responsible for ESBLs production. Genotypic method provided an efficient, rapid differentiation of ESBLs. The correct identification of the genes involved in ESBL mediated resistance is necessary for the surveillance and epidemiological studies of their transmission in hospitals. Appropriate antibiotic policy and infection control measures in hospital settings are crucial to overcome the problems associated with infections by ESBL producing strains.

\section{Limitation:}

Although utmost sincerity and dedication was investigated to carry out the study it could not go beyond limitations. As PCR reagents are expensive so all Gram-negative bacteria were not done for PCR. Samples were subjected to PCR which were only detected by DDST. Other types of genes were also not be done due to same reasons.

\section{Reference:}

1. Kapil A. The challenge of antibiotic resistance: need to contemplate. Indian J Med Res 2005; 121 : 83-91.

2. Ananthakrishnan, AN, Kanungo, R, Kumar A, Badrinath S. Detection of extended spectrum $B$-lactamase producers among Surgical wound infections and Burn patients in Jipmer. Indian Journal of Medical Microbiolology. 2000; 18(4): 160-165.

3. Paterson, D.L.; Bonomo, R.A. Extended-Spectrum betaLactamases: a Clinical Update. Clin. Microbiol. Rev. 2005; 18(4): 657-686.

4. Sousa Junior, M.A.; Ferreira, E.S.; Conceição, G.C. Betalactamases de Espectro Ampliado (ESBL): um Importante Mecanismo de Resistência Bacteriana e sua Detecção no Laboratório Clínico. NewsLab, 2004; 63: 152-174.

5. Medeiros A A. Evolution and dissemination of betalactamases accelerated by generations of beta-lactam antibiotics. Clinical Infectious Disease. 1997; 24 Suppl.1: 19-45.

6. Ben-Hamouda T, Foulon T, Ben-Cheikh-Masmoudi A, Fendri C, Belhadj O, Ben-Mahrez K. Molecular epidemiology of an outbreak of multiresistant Klebsiella pneumoniae in aTunisian neonatal ward. Journal of Medical Microbiology. 2003; 52: 427-433.

7. Eisen D, Russell EG, Tymus M, Roper EJ, Grayson ML, Turnidge J. Random amplified polymorphic DNA and plasmid analyses used in investigation of an outbreak of multiresistant K. pneumonia. J Clin Microbiol. 1995; 3: 713-7. PMID: 7751382

8. Winokur PL, Canton R, Casellas JM, Legakis N. Variations in the prevalence of strains expressing an extendedspectrum B-lactamase phenotype and characterization of isolates from Europe, the Americas, and the Western Pacific Region. Clin Infect Dis. 2001; 32 (Suppl 2): S94-103. 
9. Babini GS, Livermore DM. Antimicrobial resistance amongst Klebsiella spp. Collected from intensive care units in Southern and Western Europe in 1997-1998. $J$ Antimicrob Chemother. 2000; 45: 183-189.

10. Canton R, Novais A, Valverde A, Machado E, Peixe L, Baquero F, Coque TM. Prevalence and spread of extended-spectrum ß-lactamase-producing Enterobacteriaceae in Europe. Clin Microbiol Infect. 2008; 14 (Suppl. 1): 144-153.

11. Yusha' u MM, Kumurya AS, Suleiman L. Prevalence of Extended spectrum B-lactamases among Enterobacteriaceae in Murtala Mohammed specialist hospital, Kano. Journal of Pure and Applied Science I. 2010 ; 3(1): 169- 172.

12. Paterson,DL, Hujer KM, Hujer AM. Extended-spectrum betalactamases in Klebsiella pneumoniae bloodstream isolates from seven countries: Dominance and widespread prevalence of SHV- and CTX-M-type beta-lactamases. Antimicrobial Agents and Chemotherapy. 2003; 47: 3554-3560.

13. Bauernfeind A, Rosenthal E, Eberlein E, Holley M, Schweighart S. Spread of Klebsiella pneumoniae producing SHV-5 beta-lactamase among hospitalized patients. Infection. 1993; 21: 18-22.

14. Subramaniam G, Palasubramaniam S, Navaratnam P. SHV-5 extended-spectrum beta-lactamases in clinical isolates of Escherichia coli in Malaysia. Indian Journal of Medical Microbiology. 2006; 24: 205-207.

15. Podschun R, Ullman U. Klebsiella spp. as nosocomial pathogens: epidemiology, taxonomy, typing methods and pathogenicity factors. Clin Microbiol Rev. 1998; 11: 589-603.

16. Chaves J, Ladona MG, Segura C, Coira A, Reig R, Ampurdanés C. SHV-1 ß-lactamase is mainly a chromosomally encoded species-specific enzyme in Klebsiella pneumoniae. Antimicrob Agents Chemother. 2001; 45:2856-61.

17. Rice LB, Carias LL, Hujer AM, Bonafede M, Hutton R, Hoyen $\mathrm{C}$, et al. High level expression of chromosomally encoded SHV-1-ß-lactamase and an outer membrane protein change confer resistance to ceftazidime and piperacillin-tazobactum in a clinical isolate of Klebsiella pneumoniae. Antimicrob Agents Chemother 2000; 44:362-367

18. Jacoby GA, Munoz-Price LS. The new ß-lactamases. $N$ Engl J Med. 2005; 352: 380- 91.

19. Amita J \& Rajesh M. TEM \& SHV genes in extended spectrum ß-lactamase producing Klebsiella species \& their antimicrobial resistance pattern. Indian Journal of Medical Research. 2008; 128: 759-764.
20. Colle $J G$, Miles RS, Watt B. Tests for identification of Bacteria. In: Collee JG,. Fraser AG, Marmion BP \& Simmons A. editors. Mackie \& McCartney's Practical Medical Microbiology, 1996; 14th ed and Edinburgh, Churchill Livingstone, New York 1996; 553 -559.

21. Jarlier V, Nicolas MH, Fourier G, Phillippon A. Extended broad spectrum $\beta$-lactamases conferring transferable resistance to newer $\beta$-lactam agents in Enterobacteriaceae: hospital prevalence and susceptibility patterns. Review Infectious Disease. 1988; 10: 867-878.

22. Ercis S, Sancak B, Hasçelik G. A comparison of PCR detection of mecA with oxacillin disk susceptibility testing in different media and sceptor automated system for both Staphylococcus aureus and coagulase-negative staphylococci isolates. Indian Journal of Medical Microbiology. 2008; 26: 21-4. ISSN 0255-0857.

23. Khorshidi A, Rohani M, Moniri R. The prevalence and molecular characterization of extended-spectrum $B$ lactamases-producing Klebsiella pneumoniae isolates recovered from Kashan hospital university, Iran. Jundishapur J Microbiol. 2011; 4(4): 289-294.

24. Islam B. M.Phil, Thesis. 2008. A study on Extended Spectrum Beta-Lactamases and their rapid detection.; SSMS.

25. Rahaman W. M.Phil, Thesis, 2010. Detection of CTX-M gene in Extended Spectrum Beta-Lactamases producing organisms; SSMS.

26. Pitout JD. Multiresistant Enterobacter-iaceae: New threat of an old problem. Expert Rev Anti Infect Ther. 2008; 6: 657- 69.

27. Canton R, Novais A, Valverde A, et al. Prevalence and spread of extended-spectrum b-lactamases producing Enterobacteriaceae in Europe. Clin Microbiol Infect. 2008; 14: 144-53.

28. Lal P, Kapil A, Das BK, Sood S. Occurrence of TEM and SHV gene in extended spectrum beta-lactamases (ESBLs) producing Klebsiella spp. isolated from a tertiary care hospital. 2007; Indian Journal of Medical Research; 125: 173-8.

29. Schumachera H, Scheibelb J, Mollera JK. Crossresistance patterns among clinical isolates of $K$. pneumonia with decreased susceptibility to cefuroxime. $J$ Antimicrob Chemother. 2000; 46: 215-21. 